\title{
HUBUNGAN ANTARA PERILAKU MEROKOK DENGAN KEJADIAN PENYAKIT JANTUNG KORONER
}

\author{
${ }^{1}$ Ratnawulan Afriyanti \\ ${ }^{2}$ Janry Pangemanan \\ ${ }^{3}$ Stella Palar
}

\author{
1 Kandidat Skripsi Fakultas Kedokteran Universitas Sam Ratulangi Manado \\ ${ }^{2}$ Bagian Ilmu Penyakit Jantung dan Pembuluh Darah Fakultas Kedokteran \\ Universitas Sam Ratulangi Manado \\ ${ }^{3}$ Bagian Ilmu Penyakit Dalam Fakultas Kedokteran Universitas Sam Ratulangi Manado \\ Email: rwulanafriyanti_11_212@yahoo.com
}

\begin{abstract}
Coronary Heart Disease is an ilness wich has high mortality rate either in developed or in developing country. In the entire world, a number of patients who suffer this desease still increases each year. Cigarette, is widely acclaimed to be the cause of death in the world. Thus, the smoking habit is very dangerous to the health. A bad habit has a power in damaging a person's health, as smoking habit which can cause a person susceptible to get cardiovascular disease. Smoking is a major risk factor to get a heart disease which has strong correlation to the case of coronary heart disease. Smoking behaviour assessed based on the duration of smoking, the types of smoker, and the kind of cigarette. This research used the analytic descriptive study with a cross-sectional approach. The people being samples in this research are patients who suffer coronary heart disease in Polyclinic Center of Heart- Blood Vessel and Brain Unity of RSUP Prof. Dr. R. D. Kandou Manado. The research conducted during October December 2014. In this research, the researcher used consecutive sampling as the technique in taking samples. The data got in this research were analyzed by using Chi-Square statistical test. The result of Chi-Square experiment showed that there is a significant correlation between smoking behavior and coronary heart disease case based on the duration of smoking $(p=0,010)$, the type of smoker $(p=0,014)$ and the kind of cigarette to be smoked $(p=0,001)$. Conclusion: There is a significant correlation between the duration of smoking, the types of smoker, and the kind of cigarette to be smoked with the case of coronary heart disease.
\end{abstract}

Keywords: smoking behavior, coronary heart disease.

\begin{abstract}
Abstrak: Penyakit Jantung Koroner (PJK) adalah penyakit dengan angka mortalitas yang tinggi baik di negara maju maupun negara berkembang. Diseluruh dunia, jumlah pasien penyakit ini terus bertambah dari tahun ke tahun. Rokok secara luas telah menjadi salah satu penyebab kematian di dunia dan kebiasaan merokok merupakan perilaku yang berbahaya bagi kesehatan. Kebiasaan dan rutinitas yang merugikan memiliki kekuatan untuk merusak kesehatan seseorang seperti kebiasaan merokok yang merupakan contoh kebiasaan untuk memudahkan seseorang terkena penyakit kardiovaskuler. Merokok merupakan faktor risiko mayor untuk terjadinya penyakit jantung, dan memiliki hubungan kuat untuk terjadinya PJK. Penelitian ini bertujuan untuk mengetahui hubungan antara perilaku merokok dengan kejadian penyakit jantung koroner. Perilaku merokok dinilai berdasarkan lama merokok, tipe perokok, dan jenis rokok. Penelitian ini menggunakan studi deskriptif analitik dengan pendekatan potong lintang/cross-sectional. Sampel dalam penelitian ini adalah pasien Penyakit Jantung Koroner di Poli Klinik Pusat Jantung - Pembuluh Darah dan Otak Terpadu RSUP Prof. Dr. R. D. Kandou Manado periode Oktober 2014 - Desember 2014 dengan teknik pengambilan sampel consecutive sampling. Data dianalisa dengan menggunakan uji statistik Chi-Square. Hasil uji Chi-square menunjukkan bahwa terdapat hubungan yang signifikan antara perilaku merokok dan kejadian penyakit jantung koroner berdasarkan lama merokok $(P=0,010)$, tipe perokok $(P=0,014)$ dan jenis rokok yang dihisap $(P=$ 0,001). Simpulan: Terdapat hubungan yang signifikan antara lama merokok, tipe perokok dan jenis rokok yang dihisap dengan kejadian penyakit jantung koroner.
\end{abstract}

Kata kunci: perilaku merokok, penyakit jantung koroner 
Penyakit Jantung Koroner (PJK) merupakan kondisi yang terjadi akibat penumpukan plak di arteri jantung sehingga mengakibatkan suplai darah ke jantung menjadi terganggu. Penyakit jantung koroner ialah penyebab utama kematian di seluruh dunia, dan 3,8 juta pria serta 3,4 juta perempuan meninggal akibat penyakit tersebut setiap tahun. Penyakit Jantung Koroner juga merupakan penyebab $48 \%$ kematian akibat penyakit kardiovaskuler pada tahun 1998 di Amerika Serikat. ${ }^{1}$ World Health Organization (WHO) mencatat lebih dari 7 juta orang meninggal di seluruh dunia pada tahun 2002 akibat PJK. Angka ini diperkirakan akan meningkat hingga 11 juta di tahun $2020 .^{2}$

PJK sendiri masih menjadi masalah baik di negara maju maupun di negara berkembang. USA setiap tahunnya 550.000 orang meninggal karena penyakit ini. Sedangkan di Eropa diperhitungkan 20.000-40.000 orang dari satu juta penduduk menderita PJK. ${ }^{3}$ Penyakit jantung koroner kini menjadi penyebab utama kematian di dunia, baik pada lakilaki maupun perempuan. Berbagai faktor risiko ditengarai mendorong terjadinya PJK, sebagian dapat dimodifikasi tetapi sebagian lagi tidak. ${ }^{4}$ Salah satu faktor risiko yang bersumber dari perilaku adalah merokok. Kurang lebih 1,1 milyar penduduk dunia adalah perokok.

World Health Organization melaporkan bahwa Indonesia adalah salah satu dari lima negara dengan penduduk yang perokok terbanyak di dunia. ${ }^{2}$ Prevalensi perokok laki-laki mengalami kenaikan dari 51,2\% pada tahun 1995 menjadi $54,5 \%{ }^{5}$ Seiring dengan prevalensi yang bertambah, penyakit yang terkait dengan penggunaan tembakau dan perilaku merokok juga meningkat. ${ }^{6}$ Teori menurut Dr. Judith Mackay dan Dr. George A. Mensah, $^{7}$ menunjukkan Insiden infark miokard dan kematian akibat PJK meningkat progresif sesuai dengan jumlah rokok yang dihisap.

Berdasarkan uraian di atas maka peneliti tertarik untuk mengetahui hubungan antara perilaku merokok dengan kejadian penyakit jantung koroner.

\section{METODE PENELITIAN}

Penelitian ini menggunakan studi deskriptif analitik dengan pendekatan potong lintang/cross-sectional. Sampel dalam penelitian ini adalah pasien Penyakit Jantung Koroner di Poli Klinik Pusat Jantung - Pembuluh Darah dan Otak Terpadu RSUP Prof. Dr. R. D. Kandou Manado periode Oktober 2014 - Desember 2014 dengan teknik pengambilan sampel consecutive sampling. Data dianalisa dengan menggunakan uji statistik ChiSquare.

\section{HASIL PENELITIAN}

Dalam kurun waktu Oktober 2014 Desember 2014, Peneliti mengumpulkan 41 orang (59,4\%) dengan kasus PJK dan 28 orang (40,6\%) dengan kasus non PJK yang mempunyai kebiasaan merokok berdasarkan lama merokok, tipe perokok, dan jenis rokok yang dihisap. di Poliklinik Pusat Jantung - Pembuluh Darah dan Otak Terpadu RSUP Prof. Dr. R. D. Kandou Manado.

Sampel PJK dan Non PJK berdasarkan umur. Didapatkan sampel PJK dengan umur 21-40 tahun tidak ditemukan sedangkan non PJK berjumlah 4 orang (5,8\%). Sampel PJK dengan umur 41-60 tahun berjumlah 23 orang (33,3\%) sedangkan non PJK sebanyak 17 orang (26,4\%). Sampel PJK dengan umur 61-80 tahun berjumlah 18 orang $(26,1 \%)$ dan non PJK sebanyak 7 orang (10,1\%).

Tabel 1. Distribusi Status PJK Berdasarkan Umur

\begin{tabular}{llll}
\hline & \multicolumn{3}{c}{ Umur } \\
\cline { 2 - 4 } PJK & $\mathbf{2 1 - 4 0}$ th & $\mathbf{4 1 - 6 0}$ th & $\mathbf{6 1 - 8 0}$ th \\
\cline { 2 - 4 } Non PJK & 4 orang & 18 orang & 18 orang \\
\hline
\end{tabular}

Sampel PJK dan Non PJK berdasarkan lama merokok. Didapatkan sampel PJK sudah mempunyai riwayat merokok $>10$ tahun berjumlah 38 orang $(55,1 \%)$, dan 
yang mempunyai riwayat merokok $\leq 10$ tahun berjumlah 3 orang (4,3\%). Sampel non PJK sudah mempunyai riwayat merokok $>10$ tahun berjumlah 19 orang $(27,5 \%)$, dan yang mempunyai riwayat merokok $\leq 10$ tahun berjumlah 9 orang (13\%). Hasil analisis statistik menggunakan uji Chi-Square diperoleh nilai signifikansi $\mathrm{p}$ $=0,010$. Berdasarkan nilai tersebut dapat dikatakan bahwa terdapat hubungan yang bermakna antara lama merokok dengan pasien PJK dan non PJK di Poliklinik Pusat Jantung - Pembuluh Darah dan Otak Terpadu RSUP Prof. Dr. R.D. Kandou Manado.

Tabel 2. Distribusi Status PJK Berdasarkan Lama Merokok

\begin{tabular}{lccc}
\hline & \multicolumn{3}{c}{ Lama merokok } \\
\cline { 2 - 4 } & $\mathbf{1 0}$ th & $>\mathbf{1 0}$ th & $\boldsymbol{P}$ \\
\cline { 2 - 4 } PJK & 3 orang & 38 orang & 0,010 \\
Non PJK & 9 orang & 19 orang & \\
\hline
\end{tabular}

Sampel PJK dan Non PJK berdasarkan tipe perokok. sampel PJK sebagian besar adalah perokok berat berjumlah 24 orang (34,8\%), perokok sedang berjumlah 15 orang (21,7\%), dan perokok ringan berjumlah 2 orang (2,9\%). Sampel yang non PJK sebagian besar perokok sedang berjumlah 16 orang (23,2\%), perokok berat berjumlah 7 orang (10,1\%), dan perokok ringan berjumlah 5 orang (7,2\%). Hasil analisis statistik menggunakan uji ChiSquare diperoleh nilai signifikansi $\mathrm{p}=0$, 014. Berdasarkan nilai tersebut dapat dikatakan bahwa terdapat hubungan tipe perokok dengan pasien PJK dan non PJK di Poliklinik Pusat Jantung - Pembuluh Darah dan Otak Terpadu RSUP Prof. Dr. R.D. Kandou Manado.

Tabel 3. Distribusi Status PJK Berdasarkan Tipe Perokok

\begin{tabular}{lcccc}
\hline & \multicolumn{3}{c}{ Tipe perokok } \\
\cline { 2 - 5 } PJK & Ringan & Sedang & Berat & $\boldsymbol{P}$ \\
\cline { 2 - 5 } Non & 5 Orang & 15 orang & 24 orang & \\
PJK & Orang & 16 orang & 7 orang & 0,014 \\
\hline
\end{tabular}

Sampel PJK dan Non PJK berdasarkan jenis rokok. sampel PJK sebagian besar menghisap jenis rokok kretek dengan jumlah 34 orang $(49,3 \%)$ dan yang menghisap jenis rokok putih sebanyak 7 orang (10,1\%). Pada sampel yang non PJK sebagian besar menghisap jenis rokok putih dengan jumlah 16 orang (23,2\%) dan yang menghisap jenis rokok kretek sebanyak 12 orang (17,4\%). Hasil analisis statistik menggunakan uji Chi-Square diperoleh nilai signifikansi $\mathrm{p}=0,001$. Berdasarkan nilai tersebut dapat dikatakan bahwa terdapat hubungan jenis rokok dengan pasien PJK dan non PJK di Poliklinik Pusat Jantung - Pembuluh Darah dan Otak Terpadu RSUP Prof. Dr. R.D. Kandou Manado.

Tabel 4. Distribusi Status PJK Berdasarkan Jenis rokok

\begin{tabular}{lccc}
\hline & \multicolumn{3}{c}{ Jenis rokok } \\
\cline { 2 - 4 } PJK & Kretek & Putih & $\boldsymbol{P}$ \\
\cline { 2 - 4 } Non PJK & 12 orang & 7 orang & 0,00 \\
\hline
\end{tabular}

\section{BAHASAN}

Berdasarkan data yang diperoleh, ditemukan sampel PJK terbanyak dengan umur 41-60 tahun, yaitu berjumlah 23 orang (33,3\%). Sesuai teori yang dikemukakan oleh Peter Kabo, ${ }^{8}$ Prevalensi penyakit jantung koroner di Indonesia adalah 18,3/100.000 penduduk pada golongan usia 15-24, meningkat menjadi 174,6/100.000 penduduk pada golongan usia 45-54, dan meningkat tajam menjadi 461,9/100.000 penduduk pada usia lebih dari 55 tahun. $^{8}$

Data yang diperoleh berdasarkan lama merokok, ditemukan sampel PJK sudah mempunyai riwayat merokok $>10$ tahun berjumlah 38 orang $(55,1 \%)$ dan yang mempunyai riwayat merokok $\leq 10$ tahun berjumlah 3 orang (4,3\%). Sampel non PJK yang sudah mempunyai riwayat merokok $>$ 10 tahun berjumlah 19 orang (27,5\%), dan yang mempunyai riwayat merokok $\leq 10$ tahun berjumlah 9 orang (13\%). Teori yang 
dikemukakan oleh Fitriani Umar dkk, ${ }^{2}$ pada penelitian di Makassar tahun 2011, bahwa lama merokok $>10$ tahun merupakan salah satu faktor risiko terjadinya PJK. Semakin lama seseorang merokok, semakin besar kemungkinan untuk menderita PJK dan semakin lama pula orang tersebut terpapar oleh asap rokok. Penelitian yang dilakukan oleh Rusni Mato dkk, ${ }^{9}$ di Makassar pada tahun 2013 sebelumnya dikemukakan bahwa risiko kematian akibat penyakit jantung koroner berkurang sebanyak 50\% pada tahun pertama sesudah rokok dihentikan dan kembali seperti tidak merokok setelah berhenti merokok 10 tahun. Menurut Bustan ${ }^{\text {Dikutip dari } 10}$ lama seseorang merokok dapat di klasifikasikan menjadi kurang dari 10 tahun atau lebih dari 10 tahun. Semakin awal seseorang merokok, maka semakin sulit untuk berhenti merokok. Semakin muda usia orang merokok, akan semakin besar pengaruhnya.

Data yang diperoleh berdasarkan tipe perokok yang dinilai melalui banyak rokok yang dihisap, sampel dengan penyakit PJK sebagian besar menghisap rokok $>15$ batang/hari dengan kategori perokok berat berjumlah 24 orang (34,8\%), sedangkan sampel yang non PJK sebagian besar menghisap rokok 5-14 batang/hari dengan kategori perokok sedang berjumlah 16 orang (23,2\%). Teori Dr. Judith Mackay dan Dr. George A. Mensah mengatakan insidensi PJK dua kali lebih tinggi pada perokok dan empat kali lebih tinggi pada perokok berat dibandingkan dengan yang tidak merokok. ${ }^{7}$

Data yang diperoleh berdasarkan jenis rokok yang dihisap, bahwa pasien dengan penyakit PJK sebagian besar menghisap jenis rokok kretek dengan jumlah 34 orang (49,3\%) dan yang menghisap jenis rokok putih sebanyak 7 orang (10,1\%). Pada pasien yang non PJK sebagian besar menghisap jenis rokok putih dengan jumlah 16 orang (23,2\%) dan yang menghisap jenis rokok kretek sebanyak 12 orang $(17,4 \%)$. teori yang dikemukakan pada penelitian Fitriani Umar dkk, ${ }^{2}$ bahwa risiko PJK secara signifikan 3 kali lebih besar pada orang yang merokok kretek. Sebagaimana diketahui bahwa rokok kretek memiliki kandungan nikotin dan tar yang cukup tinggi. Di Indonesia ada dua jenis produk rokok yang dikenal yaitu rokok putih dan rokok kretek. rokok kretek, yakni rokok yang memiliki ciri khas adanya campuran cengkeh pada tembakau. Sedangkan rokok putih, adalah rokok dengan atau tanpa filter dan cengkeh hanya menggunakan tembakau. ${ }^{11}$

\section{SIMPULAN}

Berdasarkan hasil penelitian dapat disimpulkan bahwa terdapat hubungan bermakna antara perilaku merokok berdasarkan lama merokok, tipe perokok dan jenis rokok dengan kejadian penyakit jantung koroner.

\section{DAFTAR PUSTAKA}

1. Burns D, Kumar V. Jantung. In: Kumar V, Cotran R, Robbins S, editors. Buku Ajar Patologi. $7^{\text {th }}$ Edition. Jakarta: EGC, 2007.

2. Umar F, Citrakesumasari, Jafar $\mathbf{N}$. Perilaku merokok dan lingkungan pemukiman pasien rawat jalan penyakit jantung koroner di makassar. Media Gizi Masyarakat Indonesia. 2011;1(1):21-8.

3. Salim AY, Nurrohmah A. Hubungan olahraga dengan kejadian penyakit jantung koroner di RSUD dr. moewardi. Gaster.2013;10(1):48-56.

4. Rilantono Lily I. Penyakit kardiovaskular. Jakarta: Fakultas Kedokteran Universitas Indonesia, 2012. p. 121.

5. Rizkiani M, Widyastuti RH. Hubungan antara stress dengan perilaku merokok pada pegawai negeri sipil laki-laki. Jurnal Kesehatan Universitas Diponegoro. 2012.

6. Prabandari YS, Ng Nawi, Padmawati RS. Kawasan tanpa rokok sebagai alternative pengendalian tembakau studi efektivitas penerapan kebijakan kampus bebas rokok terhadap perilaku dan status merokok mahasiswa di fakultas kedokteran UGM, yogyakarta. Manajemen pelayanan kesehatan. 2009;12:218-25.

7. Mackay J, Mensah A George. The Atlas 
of Heart Diseases and Stroke. CDC WHO, 2004.

8. Kabo Peter. Mengungkap pengobatan penyakit jantung koroner. Jakarta: PT Gramedia Pustaka Utama, 2008. p. 423.

9. Savia FF, Mato Rusni, Suarnianti. Pengaruh merokok terhadap terjadinya penyakit jantung koroner (PJK) di RSUP dr. wahidin sudirohusodo makassar. STIKES Nani Hasanuddin Makassar. 2013;1(6):1-6.

10. Anwar TB. Faktor risiko penyakit jantung koroner. e-USU Repository. 2004:1-15.

11. Kusuma DA, Yuwono SS, Wulan SN. Studi kadar nikotin dan tar sembilan merk rokok kretek filter yang beredar di wilayah kabupaten nganjuk. J Tek. 2010;5(3):151-5. 